\title{
\$sciendo
}

Ethics \& Bioethics (in Central Europe), 2019, 9 (1-2), 3-10

DOI:10.2478/ebce-2019-0003

\section{Thinking and behaving "Otherwise": An anthropological enquiry into utopia, image and ethics}

\author{
Roberto Franzini Tibaldeo ${ }^{1}$
}

\begin{abstract}
The word "utopia" was coined by Thomas More and refers to the unreal and ideal state described in his Utopia, first published in 1516. Following the example of Plato's Republic, More as well as other thinkers and writers of the $16^{\text {th }}$ and $17^{\text {th }}$ century reflect on the political relevance of utopia and provide unique accounts of ideal, just, and perfect "no places", as paradigms and standards of social, political, and religious reformation of the coeval world. However, the political significance of utopia relies on a basic anthropological feature, which incidentally is already underlined by More: the relationship between imagination and experience. This means that: 1) the human being's "eidetic" freedom is characterised by the inseparable relationship between imagination, reflection, experience and action; 2) utopia is capable of disclosing the transformative and normative features related to the human being's constitution; 3) utopia can be fruitfully used to motivate human will and mobilise support for human flourishing. In this article I endeavour to show that among contemporary philosophers it is Hans Jonas who most fully develops the anthropological significance of utopia by investigating the very relationship between imagination and experience, and by underlining how the eidetic and reflective constitution of the human being leads to ethics. As a further goal, I wish to highlight that the anthropological relevance of utopia can shed light on our imaginative and ambivalent nature, and provide a practical and educational basis for the achievement of an "ethics of images" for the current digital era. For this purpose I shall draw on the thinking of Marie-José Mondzain and Jean-Jacques Wunenburger, among other scholars.
\end{abstract}

Keywords: utopia, image, imagination, imagery, ethics, education, Hans Jonas, Marie-José Mondzain, JeanJacques Wunenburger

\section{Introduction}

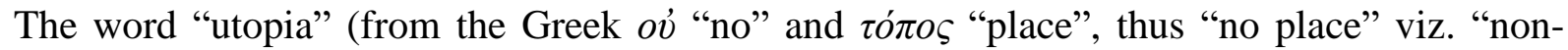
existing place") was coined by Thomas More and refers to the unreal and ideal state described in his book Libellus vere aureus nec minus salutaris quam festivus de optimo reipublicae statu, deque de nova Insula Utopia [A Truly Golden Account of the Best State of a Commonwealth and of the New Island of Utopia], which was first published by the Louvain printer Thierry Martens in 1516 (More, 1995). Following the example of Plato's Republic, More and other thinkers and writers of the $16^{\text {th }}$ and $17^{\text {th }}$ century (like Tommaso Campanella, Francesco Patrizi, Francis Bacon and James Harrington) reflect on the political relevance of utopia and provide unique accounts of ideal, perfect and just "no places", as paradigms and standards of social, political, and religious reformation of the coeval world.

However, the political significance of utopia (both as an unrealizable or abstract model, and as a method of criticizing and reforming present-day society or state) relies on a basic anthropological feature, which incidentally is already underlined by More: the essential and twofold relationship between imagination and experience. What I mean by this is the human being's desired way of life and worldly condition. As noted by Ruth Levitas, we are "essentially capacity-bearing beings [...] possessed of an innate context-transcending capacity", according to which "we seek always to live beyond ourselves". It is "an emergent property of the human mind to create the infinite out of the finite; one innate characteristic of the mind is its nonmechanical character, its capacity to outrun and subvert the given, in short, to imagine. While we are always and everywhere constrained and constructed by historical

\footnotetext{
${ }^{1}$ Université catholique de Louvain, Louvain-la-Neuve (Belgium); email: roberto.franzini@uclouvain.be
} 
circumstances, these circumstances vary in the extent to which they permit and enable human agency, and they never shape us fully [...]. Transcendence is the capacity to imagine ourselves beyond and to act upon, rather than simply react to, the external structures around us" (Levitas, 2013, pp. 184-185). Rather than a goal, utopia is thus "best regarded as a method that is both hermeneutic and constitutive. In its hermeneutic mode, it identifies the various and fragmentary expressions of utopian desire. In its constitutive or constructive mode, as the Imaginary Reconstitution of Society, it [...] expands the range of possibilities" (Levitas, 2013, pp. 217218).

This means that: 1) the human being is - as Hans Jonas would say - an "eidetic" being characterised by the inseparable relationship between imagination, reflection, experience and action (Jonas, 1966); 2) utopia is capable of disclosing the transformative and normative features related to the human being's constitution, namely the "imaginative engagement with a model which can modify our attitudes and even qualify our conduct" (Baker-Smith, 2014); 3) finally, since it "operates at the level of affect as well as intellect" (Levitas, 2013, p. 218), utopia can be fruitfully used to motivate human will and mobilise its support to human flourishing.

Among contemporary philosophers it is Hans Jonas who fully develops the anthropological significance of utopia by investigating the very relationship between imagination and experience, and underlining how the eidetic and reflective constitution of the human being leads to ethics. This is the basis of Jonas" "veneration for the image of man, turning into trembling concern for its vulnerability" (Jonas, 1984, p. 201) and for his criticism of specific aspects of the anthropological, political, and technological utopias stemming from modernity, such as the "Baconian ideal", the "utopia of the coming "true man", the "idea of progress", and "Marxist utopianism" (Jonas, 1984). As a further goal, I wish to suggest that the anthropological relevance of utopia can shed light on our imaginative and ambivalent nature, and provide a practical and educational basis for the achievement of an "ethics of images" for the current digital era. For this purpose I shall draw on the thinking of Marie-José Mondzain and JeanJacques Wunenburger, among other scholars.

\section{The anthropological significance of utopia}

In order to introduce the anthropological significance of utopia, I would like to refer to a conversation held in 1964 between Ernst Bloch and Theodor Adorno on the contradictions of utopian longing or desire, published under the title Etwas fehlt-Something's Missing (Bloch \& Adorno, 1988). Among other issues, Bloch and Adorno discuss the relationship between utopia (as a way of thinking) and utopian accomplishments. Indeed, utopia refers to something more than mere accomplishment. Utopia is something which "is not yet in the sense of a possibility; that it could be there if we could only do something for it" (Bloch \& Adorno, 1988, p. 3). Adorno agrees and adds: "Whatever utopia is, whatever can be imagined as utopia, this is the transformation of the totality. And the imagination of such a transformation of the totality is basically very different in all the so-called utopian accomplishments - which, incidentally, are all really like you say: very modest, very narrow. It seems to me that what people have lost subjectively in regard to consciousness is very simply the capability to imagine the totality as something that could be completely different" (Bloch \& Adorno, 1988, pp. 3-4). Moreover, what hinders the imagination and understanding of utopia is the fact that - states Adorno - "One may not cast a picture of utopia in a positive manner. Every attempt to describe or portray utopia in a simple way, i.e., it will be like this, would be an attempt to avoid the antinomy of death and to speak about the elimination of death as if death did not exist. That is perhaps the most profound reason, the metaphysical reason, why one can actually talk about utopia only in a negative way" (Bloch \& Adorno, 1988, p. 10).

Bloch remarks: "'negative' does not mean 'in depreciation"” (Bloch \& Adorno, 1988, p. 10). Adorno agrees and further adds: This is the reason why we have the "the commandment not to 
'depict' utopia or the commandment not to conceive certain utopias in detail [...]. What is meant there is the prohibition of casting a picture of utopia actually for the sake of utopia, and that has a deep connection to the commandment 'Thou shalt not make a graven image!' This was also the defence that was actually intended against the cheap utopia, the false utopia, the utopia that can be bought" (Bloch \& Adorno, 1988, pp. 10-11).

Bloch entirely agrees with Adorno and specifies further the risk related to conjuring up utopian visions: "This leads us back again to [...] the actual state of affairs where utopia becomes diffused, in that I portray it as being [seiend] or in that I portray it as achieved even if this is only in instalments. As instalment of having been achieved is already included when I can portray it in a book. Here it has at least become real already and, as you said, 'cast into picture'. One is thus deceived. It is diffused, and there is a reification of ephemeral or nonephemeral tendencies, as if it were already more than being-in-tendency, as if the day were already there. Thus, the iconoclastic rebellion against such reification is now in this context completely correct. And displeasure must keep on its guard, for which death most certainly provides a continual motivation" (Bloch \& Adorno, 1988, p. 11).

So, according to Bloch and Adorno, it is incorrect to make "graven images" of utopia, since they would end up reifying utopia's critical, dialectical and never resting impulse to a "totality of the end". In other words, Bloch and Adorno's 'iconoclasm' is rooted in their will to avert iconolatry (or iconodulia), i.e. the worship of reified images or instalments of utopia, an attitude which indeed results in the misconceived identification of utopia (as a way of thinking) with utopian accomplishments. I believe that this argument is supported by the basic assumption that the notion of image is something in itself static and non-performative, and thus incapable of coping with a dynamic dialectical effort to truth.

But what if the notion of image was conceived in a different way, namely a 'performative' way? What if our understanding of 'image' actively underwent - let us call it - a 'performative revolution'? In what sense would this revolution affect our understanding of utopia? In brief, what I wish to argue is: A) as already stated by Bloch and Adorno, we have the duty to avert iconolatry, i.e. we do have to maintain the difference between utopia (as a way of thinking) and utopian accomplishments; B) however, the most effective way of attaining this goal might not be an iconoclastic stance, but an attitude thoroughly based on 'iconophilia', where of course the notion of 'eikon' or 'image' has undergone a performative renovation. Indeed, I think that the iconophilic way of thinking rather than the iconoclastic is capable of providing 1) a thorough understanding of our imaginative and ambivalent nature, 2) a renewed view of utopia (as an practical experience and a way of thinking and behaving "otherwise" [Levitas, 2013]), and 3) a key to understanding some risks related to utopianism.

Let me briefly hint at the steps of this possible counterproposal, which draws on the philosophical reflections of Hans Jonas, Marie-José Mondzain and Jean-Jacques Wunenburger among others.

\subsection{The image is intrinsically performative, related to desire and central to normativity}

Among the most interesting findings of Hans Jonas' philosophical-anthropological enquiry is the following: the image proves to be central to the human constitution and is redefined in 'performative' terms. Let me briefly summarise his argument. In order to understand the human specificity Jonas rephrases Cassirer's “animal symbolicum" (Cassirer, 1944, p. 44; Jonas, 2016, ch. V, p. 37; see also Jonas, 1966, pp. 184-185) as "homo pictor" (Jonas, 1966, pp. 157-175): the human being is characterised by a unique degree of inner and external freedom, which is evident in a symbolic nature, namely something related to sight (perception), image, and (bodily) movement. In Jonas' words: the external existence of manmade images (like primitive graffiti) "as a result of human activity reveals also a physical aspect of the power that the image faculty wields: the kind of command that man has over his body. Indeed, the inner command 
of the eidos, with all its freedom of mental drafting, would remain ineffective had it not also the power to guide the subject's body in execution. Only in this way imagination [Vor-stellung] can rise to representation [Dar-stellung], although representation descends exactly from imagination and the bodily freedom repeats each time the freedom of imagination [...]. What we here have is a trans-animal, uniquely human fact: eidetic control of motility, that is, muscular action governed not by set stimulus-response pattern but by freely chosen, internally represented and purposely projected form" (Jonas, 1966, p. 172, modified according to Jonas, 2010, pp. 300-301).

Incidentally, worth underlining is that by referring to the very same religious (viz. biblical Jewish) tradition employed by Adorno and Bloch to support their iconoclastic view, Jonas achieves quite a different result when commenting on Genesis, 2.19: "Image-making each time re-enacts the creative act that is hidden in the residual name: the symbolic making-over-again of the world. It exhibits what the use of names takes for granted: the availability of the eidos as an identity over and above the particulars, for human apprehension, imagination, and discourse" (Jonas, 1966, p. 173). Jonas highlights two further issues: 1) the image-faculty and its freedom happen to be "geared to will or desire, with the result either of supplanting the evidence of perception by what one would have it to be (wishful thinking), or of opposing it by what one would make it to be (projective thinking)" (Jonas, 1966, p. 177). These "voluntaristic exercises of negative-positive freedom" are "the source both of illusory belief and of creative utopia" (Jonas, 1966, pp. 177-178) and provide a broad understanding of what the human being truly is (Jonas, 1966, p. 185). In short, the practical relevance of the image is underlined here. 2) The image-faculty gives rise to self-reflection, as the basis of that typically human experience of in Ricœur's words - "oneself as another": "Man models, experiences, and judges his own inner state and outward conduct after the image of what is man's. Willingly or not he lives the idea of man - in agreement or in conflict, in acceptance or in defiance, in compliance or in repudiation, with good or with bad conscience. The image of man never leaves him, however much he may wish at times to revert to the bliss of animality. To be created in the image of God means to have to live with the image of man. That image is worked out and entertained in the verbal intercommunication of society, and thus the individual finds it ready-made and thrust upon him. As he learns from others to see things and to speak about them, so he learns from them to see himself and to express what he sees there 'in the image and likeness' of the established pattern. But learning this, learning to say 'I', he potentially discovers his own identity in its solitary uniqueness. A private objectivity of the self is thus in constant rapport with the public image of man and through its own exteriorization contributes to the continuous remaking of the latter - the anonymous share of each self in the history of all" (Jonas, 1966, pp. 185-186). What is underlined here is the role played by the image in the human being's normative experience, namely in the effort to answer the "question of what life befits man" (Jonas, 1966, p. 209) or "what can the best society look like? Which is the best framework for the best human life?" (Jonas \& Gebhardt, 1994, p. 209). The image is indeed central in this regard, since it gives rise to reflection, which in turn provides the means to cope with an extreme degree of distance from the world. It is thanks to this dynamic interplay of self and world that eidetic freedom turns into free will, thus giving rise to morality (Jonas, 1966).

\subsection{The image is dialectical, ambivalent and open (undecided), and leads to the ambiguity of human free will}

The practical-performative relevance of the image is the core of Jonas' anthropology. I would like to underline the novelty of this approach by interpreting it in the light of a present-day trend in image theory represented by the Algerian-French scholar Marie-José Mondzain. In particular, I would like to draw attention to the transition from eidetic freedom to free will. 
Mondzain states that the key issue related to images is no longer their static resemblance to something, but representation as the performative deed of "building the view of individuals who share a common space. The question is no longer addressed to the object as 'What does the image show?', but to the subject as 'What do we see?' and 'Who decides what is to be seen?'" (Mondzain, 2003, p. 153). The image's object remains "undecided" until when, thanks to the subjects (viz. those who enquire into the meaning of the world's appearance), the process of visibility takes finally place. Images are characterized by a peculiar "power" (Mondzain, 2003, pp. 27-28), namely a way of moving (emotionally) and motivating (to act). Nevertheless, this power is ambivalent (incidentally, Jonas also reflects on the ambivalence of images in Jonas, 1966, pp. 157-175) and so - according to Mondzain - the related process of visibility can result in two opposite outcomes: 1) idolatry, where individual freedom is subdued to the authority of the image and of its creators, or 2) iconophilia, where individual freedom has the opportunity to exercise its own capacity and freedom of judgement without any imposition by an authoritative power and with the aim of achieving a common view. Only in this second case is the image capable of fully disclosing its evaluative (or normative) significance and of stimulating the conscious (viz. responsible) exercise of free will. Indeed, "the image is precisely what urges thinking to become critical. The visible is nothing given; it is everyone's duty to build the object of what one desires to see" (Mondzain, 2003, p. 166).

To sum up, the centrality of the image in the human constitution evidences 1) the latter's ambivalent feature (idolatry as a continual temptation; iconophilia as an ongoing possibility), 2) the mutual relationship between freedom and responsibility (in this regard, Mondzain states for instance that "To produce an image and to present it to sight means to be able to bear responsibility for it. This is how we achieve a perspective which is able to judge and to be responsible" [Mondzain, 2003, p. 166]), and finally 3) the need for a new 'performative' philosophy, which is capable of thinking through and thanks to images (see also Wiesing, 2016).

\subsection{The image and its ambivalence opens to ethics and demands ethical (as well as political, pedagogical, etc.) enquiry}

Let me briefly restate that, according to Jonas, the human being's eidetic and reflective constitution is at the heart of the essential ambiguity of his or her freedom and free will (Jonas, 1966 and Jonas, 1984 repeatedly underline this aspect). This feature calls for ethical reflection - an enquiry made especially urgent in times of techno-digital development, which on the one hand increases the power of human action as well as the magnitude of its effects and on the other hand is nevertheless incapable of coping with the related ethical issues arising at an environmental, bioethical, economic, social and political level (see Floridi, 2014 among others). What I would like to emphasise is the role played in this regard by images (indeed, it is not by chance that Jonas often recalls the ethical centrality of the so-called "image of man" - a topic that I do not have time to develop further), which are central to how human beings live and act in the world.

To give an example, I would like to hint at the relationship between image and the closely connected notion of imagery, as conceived by Jean-Jacques Wunenburger among others. Wunenburger shares Jonas and Mondzain's basic assumption that image and imagery are intrinsically ambivalent. This is why ethics is demanded: the value of imagery "relies not only on its products, but on their utilization. Thus, imagination requires ethics or even a culture of images" (Wunenburger, 2003, p. 29). At the basis of this ethical claim resides the belief that imagery may be variously used in order to "free us from immediacy, from the existing and perceived reality, without confining us in the abstractions of thinking" (Wunenburger, 2003, p. 63). Among the functions performed by imagery, the most interesting for the topic under consideration is the one Wunenburger defines as "practical institutive orientation" ("Visée 
instituante pratique" - Wunenburger, 2003, p. 74), which offers relevant motivational resources: "the imagery provides social subjects with that hope, expectation, and proactivity which are necessary to organise or challenge, namely to promote those deeds which form the life of the social body. Without the mediation of imagery societies risk to be nothing but static and functional organisations similar to anthills [...]. Imagery envisages collateral possibilities which may be fulfilled. Individuals and people recognise in the imagery related to their dreams what are the aims of their present and future deeds. The myths of the future fascinate, galvanize the energies, nourish those projects of transformation of the present" (Wunenburger, 2003, pp. 78-79). Jonas is also well aware of this propulsive, eidetic and reflective human feature - sad to say, a feature currently disregarded in favour of the "self-corrective mechanics of the interplay of science and technology" (Jonas, 1966, p. 208), which is allegedly capable of clarifying the "issue of the good" (Jonas, 1966, p. 209) and the human being's "ultimate ends" (Jonas, 1966, p. 208), but is in fact unlikely to do so unless humanity also plays a part in this effort (Harari, 2017).

\subsection{Why utopia after all?}

Following Jonas, we could say that utopia is what we need in order to preserve our humanity. We need utopia to steer clear of the reductive shortcomings and threats of present-day technological and political utopianisms - namely those programmes of (collective) action, which tend to misuse hope in order to realize authenticity and the "true man" (Jonas, 1984). These utopianisms are unsatisfactory precisely because the value and dignity of the present is erased and this, according to Jonas, prevents human existence from being duly understood and preserved in its eidetic and reflective capacity, ambiguity and "partiality" ("ek merous", 1 Cor. 13,9 ff. quoted in Jonas, 2000, p. 28). In his own words: "When I found myself, unexpectedly, standing before Giovanni Bellini's Madonna triptych in the sacristy of St. Zaccaria in Venice, I was overcome by the feeling: here had been a moment of perfection, and I am allowed to see it. Eons had conspired toward that moment, and in eons it would not return if left unseized: the moment when, in a fleeting 'balance of colossal forces', the All seems to pause for the length of a heartbeat to allow a supreme reconciliation of its contradictions in a work of man. And what this work of man holds fast is absolute presence in itself - no past, no future, no promise, no succession, whether better or worse, not a prefiguration of anything, but rather timeless shining in itself. That is the 'utopia' beyond every 'not yet', scattered moments of eternity in the flux of time - and Bloch was very well aware of that. But they are a rare gift, and we should not forget over them the great tormented souls, to whom we owe perhaps even more (and something other than instruction about a 'not yet'): in them, too, there is the ageless present of man. That there are yet things to come is indeed always part of what is and each time our task, but to read it into the testimony of the past for our benefit and edification, as if only we at last could lead it in us beyond itself and to its destination, as if it had waited for us, nay, had been 'meant' for us in the first place - that is to rob it of its inherent own right, and ourselves of its true gift" (Jonas, 1984, p. 200).

In what sense are these reflections still to be considered 'utopian'? In what sense - to quote the sentence Bloch borrows from Brecht - "Something's [still] missing"? Indeed, I believe that - as stressed by Jonas - utopianism has to be reframed as no longer a purely ex negativo approach focused on the Blochian dialectics of "displeasure" and hope, but a more complex and imaginative one revolving around "fear", "reverence/veneration [Ehrfurcht]" and "hope" - in a word: responsibility, which is not at all at odds with desire, since responsibility provides - both ex negativo through fear and ex positivo through the "image of man" we in living

\footnotetext{
${ }^{2}$ See the Preface and the final pages of the German Das Prinzip Verantwortung (Jonas, 2015, pp. 15-19, 414420; the latter pages are slightly different from the corresponding English translation). On "reverence" as a feeling, see as well Jonas, 1984, pp. 88-90.
} 
entertain - critical guidelines for the dutiful perpetuation and flourishing of humanity, freedom and desire, along with its openness and ambiguity (viz. its unavoidable exposure to the risks of annihilation, alienation, reification, commodification, etc. - Sargent, 2010; Jacoby, 2005).

\section{Conclusions}

In this article I endeavoured to clarify in what sense utopia is essentially and primarily endowed with anthropological relevance. Utopia expresses what makes us human, namely our capacity to think and behave "otherwise" and "beyond ourselves", and to be simultaneously "future-" and "present-oriented" (Levitas, 2013, p. 84). It expresses our "eidetic" and imaginative nature, along with the unavoidable degree of ambivalence related to this peculiar image-centred experience of freedom. Steering clear of 'idolatry' and pursuing 'iconophilia' requires a constant effort in terms of awareness, care and attention, especially in the current techno-digital image- and visualisation-based era characterised by the tendency to "capture our gaze" and overrule our ability to "pay attention" (Waldenfels, 2006; Citton, 2014; see also Depraz 2014). The need to find effective ways of imagining a more durable relationship between present and future demands of us that we be responsible - and becoming responsible entails the conjoint mobilisation of reason and affect (see for instance Jonas' "feeling of responsibility" [Jonas, 1984]), as well as the "education of desire" (Abensour, 1999) through "critical, creative and caring” dialogue (Lipman, 2003).

\section{References}

ABENSOUR, M. (1999): William Morris: The politics of romance. In: M. Blechman (ed.): Revolutionary romanticism. San Francisco: City Lights Books, pp. 125-161.

BAKER-SMITH, D. (2014): Thomas More, in Stanford Encyclopedia of Philosophy. [online] [Retrieved October 8, 2018] Available at: https://plato.stanford.edu/entries/thomas-more/.

BLOCH, E. \& ADORNO, Th. W. (1988): Something's missing: A discussion between Ernst Bloch and Theodor W. Adorno on the contradictions of utopian longing. In: E. Bloch: The utopian function of art and literature, selected essays. Cambridge, MA \& London: MIT Press, pp. $1-17$.

CASSIRER, E. (1944): An essay on man: An introduction to a philosophy of culture. Garden City, NY: Doubleday Anchor Books.

CITTON, Y. (2014): Pour une écologie de l'attention. Paris: Seuil.

DEPRAZ, N. (2014): Attention et vigilance. À la croisée de la phénoménologie et des sciences cognitives. Paris: Presses Universitaires de France.

FLORIDI, L. (2014): The fourth revolution: How the infosphere is reshaping human reality. Oxford: Oxford University Press.

HARARI, Y. N. (2017): Homo deus: A brief history of tomorrow. New York: HarperCollins. JACOBY, R. (2005): Picture imperfect: Utopian thought for an anti-utopian age. New York: Columbia University Press.

JONAS, H. \& GEBHARDT, E. (1994): Naturwissenschaft versus Natur-Verantwortung. In: D. Böhler (ed.): Ethik für die zukunft. im diskurs mit Hans Jonas. München: Beck, pp. 197-212.

JONAS, H. (1966): The phenomenon of life: Toward a philosophical biology. New York: Harper \& Row.

JONAS, H. (1979/1984): The imperative of responsibility: In search of an ethics for the technological age. Chicago: University of Chicago Press.

JONAS, H. (2000): Letter to A. Lowe, 18 November 1964 on Bloch and the meaning of utopia. In: Ragion pratica, 15, pp. 28-31 (in German).

JONAS, H. (1973/2010): Organismus und Freiheit. Ansätze zu einer philosophischen Biologie (German modified version of Jonas 1966). In: Kritische Gesamtausgabe der Werke von Hans Jonas, vol. I/1. Freiburg: Rombach, pp. 1-359. 
JONAS, H. (1979/2015): Das Prinzip Verantwortung. Versuch einer Ethik für die technologische Zivilisation. In: Kritische Gesamtausgabe der Werke von Hans Jonas, vol. I/2. Freiburg: Rombach, pp. 1-420.

JONAS, H. (2016): Organism and Freedom: An Essay in Philosophical Biology. In: Kritische Gesamtausgabe der Werke von Hans Jonas, vol. II/3. Freiburg: Rombach. [online] [Retrieved October 8, 2018] Available at: http://hans-jonas-edition.de/wp-content/uploads/2016/ 10/KGA

Hans-Jonas-Kontext-Bd.-I1-Organism-and-Freedom.pdf. Originally composed in the 1950s and previously unpublished.

LEVITAS, R. (2013): Utopia as method: The imaginary reconstitution of society. New York: Palgrave Macmillan.

LIPMAN, M. (2003): Thinking in education, 2nd edition. Cambridge: Cambridge University Press.

MONDZAIN, M. J. (2003): Le Commerce des regards. Paris: Seuil.

MORE, Th. (1995): Utopia: Latin text and English translation, edited by G. M. Logan, R. M. Adams and C. Miller. Cambridge: Cambridge University Press.

SARGENT, L. T. (2010): Utopianism: A very short introduction. Oxford: Oxford University Press.

WALDENFELS, B. (2006): Grundmotive einer Phänomenologie des Fremden. Frankfurt am Main: Suhrkamp.

WIESING, L. (2016): The visibility of the image: History and perspectives of formal aesthetics. New York \& London: Bloomsbury.

WUNENBURGER, J. J. (2003): L'imaginaire. Paris: PUF. 